\title{
Facilitator's guide for training on monitoring and evaluation of social and behavior change communication health programs
}

Praween Kumar Agrawal

Population Council

Kumudha Aruldas

Population Council

M.E. Khan

Population Council

Subrato Mondal

Follow this and additional works at: https://knowledgecommons.popcouncil.org/departments_sbsr-rh

Part of the Demography, Population, and Ecology Commons, Family, Life Course, and Society Commons, International Public Health Commons, Public Health Education and Promotion Commons, and the Women's Health Commons

How does access to this work benefit you? Let us know!

\section{Recommended Citation}

Agrawal, Praween Kumar, Kumudha Aruldas, M.E. Khan, and Subrato Mondal. 2014. "Facilitator's guide for training on monitoring and evaluation of social and behavior change communication health programs." New Delhi: IHBP and Population Council. 


\section{FACILITATOR'S GUIDE}

\section{MONITORING AND EVALUATION OF SOCIAL AND BEHAVIOR CHANGE COMMUNICATION HEALTH PROGRAMS}

Praween K. Agarwal

Kumudha Aruldas

M.E. Khan

Subrato K. Mondal

2014 


\section{SUGGESTED CITATION}

Agrawal P.K., K. Aruldas, M.E. Khan \& Subrato K. Mondal, 2014. Facilitator's guide for training on monitoring and evaluation of social and behavior change communication health programs. New Delhi: IHBP, Population Council.

\section{DISCLAIMER}

This document is made possible by the generous support of the American people through the United States Agency for International Development (USAID) under the terms of Contract No. AID-386-TO11-00001. The content is the sole responsibility of the Improving Healthy Behaviors Program (IHBP) partner Population Council, and does not necessarily reflect the views of USAID or the United States Government. 


\section{TABLE OF CONTENTS}

Acknowledgements $\quad$ v

Abbreviations

$\begin{array}{ll}\text { Introduction } & 01\end{array}$

Module 1: Basics of Social and Behavior Change Communication 05

$\begin{array}{ll}\text { Module 2: Introduction to Monitoring and Evaluation } & 10\end{array}$

Module 3: Monitoring and Evaluation of SBCC Programs Through a Logical Framework Matrix $\quad 15$

Module 4: Monitoring of SBCC Programs at District and Block Levels 19

Module 5: Research Designs for Evaluating SBCC Programs 23

Module 6: Role of Qualitative Methods in Evaluating SBCC Programs 30

Module 7: Developing Terms of Reference for Evaluating SBCC Programs 37 


\section{ACKNOWLEDGMENTS}

We are thankful to Rita Leavell, Director/Chief of Party of the Improving Healthy Behaviors Program (IHBP), India/FHI360 for extending their full support to the development of this manual on basic monitoring and evaluation of social and behavior change communication programs.

We especially thank and appreciate the contributions of other FHI360 colleagues, Orlando Hernandez, Senior M\&E Advisor; Phillis Kim, Project Director, Social Marketing \& Communication; and Elizabeth Ryan, Associate Director, Social Marketing \&Communication, for their valuable comments to make this manual contextual and comprehensive.

We acknowledge the contribution of Shabbir Syed Ali, Population Council, in formatting this document. 


\section{ABBREVIATIONS}

ANM

Auxiliary Nurse Midwife

ASHA Accredited Social Health Activist

BCC Behavior Change Communication

FP

Family Planning

IEC

Information, Education, and Communication

IHBP Improving Healthy Behaviors Program

IPC Interpersonal Communication

M\&E Monitoring and Evaluation

MIS Management Information System

SBCC Social and Behavior Change Communication

TOR Terms of Reference

TV Television

USAID United States Agency for International Development

VHSC Village Health and Sanitation Committee 


\section{INTRODUCTION}

Social and behavior change communication (SBCC) interventions are now incorporated within state project implementation plans and increasing resources are being allocated for SBCC activities. This has made it necessary to closely monitor SBCC activities and evaluate them in terms of reach and effectiveness among intended audiences. This demands a serious effort to build capacity of monitoring and evaluation (M\&E) personnel to monitor and evaluate performance of SBCC activities. Therefore, FHI 360's Improving Healthy Behaviors Program (IHBP), funded by USAID, aims to provide technical assistance to strengthen capacities of public program managers at the national, state, and district level to monitor and evaluate SBCC interventions for health.

The goal of this Facilitator's Guide is to train a cadre of master trainers on M\&E of SBCC activities at the national and state levels who would further build capacity of staff responsible for M\&E of SBCC activities within the state at the district level. Depending on the participants-whether program managers, monitoring officers, or evaluators-trainers may modify the emphasis on the content of each module.

\section{ABOUT THE FACILITATOR'S GUIDE}

This Facilitator's Guide includes instructions for the trainers on the following seven modules for monitoring and evaluating SBCC programs:

Module 1: Basics of Social and Behavior Change Communication

Module 2: Introduction to Monitoring and Evaluation

Module 3: Developing Logical Framework Analysis for SBCC Programs

Module 4: Monitoring of SBCC Programs at District and Block Levels

Module 5: Research Designs for Evaluating SBCC Programs

Module 6: Role of Qualitative Methods in Monitoring and Evaluating SBCC Programs

Module 7: Developing Terms of Reference for Evaluating SBCC Programs

\section{WORKSHOP SCHEDULE}

This Facilitator's Guide is designed for a3-day workshop. Following is a broad workshop schedule. Facilitators should feel free to tailor this schedule to suit their workshop objectives and participants' 
needs. However, they should be careful to ensure sufficient time is allotted for participants to apply and reflect on the concepts included.

\begin{tabular}{|c|c|c|c|}
\hline \multicolumn{4}{|c|}{ Workshop Schedule } \\
\hline & Day 1 & Day 2 & Day 3 \\
\hline Morning (Session 1) & $\begin{array}{l}\text { Welcome and introduction } \\
\text { Pretest } \\
\text { - Module 1: Basics of SBCC }\end{array}$ & $\begin{array}{l}\text { Module 4: Monitoring of } \\
\text { SBCC programs at district } \\
\text { and block level }\end{array}$ & $\begin{array}{l}\text { Module 6: Role of qualita- } \\
\text { tive methods in evaluating } \\
\text { SBCC programs }\end{array}$ \\
\hline Morning (Session 2) & $\begin{array}{l}\text { - Module 2: Introduction to } \\
\text { monitoring and evaluation }\end{array}$ & $\begin{array}{l}\text { Module 5: Research de- } \\
\text { signs for evaluating SBCC } \\
\text { programs }\end{array}$ & $\begin{array}{l}\text { Module 6: Role of qualita- } \\
\text { tive methods in evaluating } \\
\text { SBCC programs }\end{array}$ \\
\hline Afternoon (Session 3) & $\begin{array}{l}\text { Module 3: Developing a } \\
\text { logical framework analysis } \\
\text { for a SBCC program }\end{array}$ & $\begin{array}{l}\text { Module 5: Research de- } \\
\text { signs for evaluating SBCC } \\
\text { programs }\end{array}$ & $\begin{array}{l}\text { Module 7: Developing } \\
\text { terms of reference for eval- } \\
\text { uating SBCC programs } \\
\text { Clarifying questions from } \\
\text { all sessions and distribution } \\
\text { of Resources } \\
\text { Posttest } \\
\text { Closing }\end{array}$ \\
\hline
\end{tabular}

\section{SETTING UP THE WORKSHOP VENUE}

- Arrange seating so that the participants can see the resource persons, one another, flip charts, and screens. This facilitates a principle of "Learning Together."

- Arrive early to set up to ensure that all pre-workshop arrangements are carried out. This is especially important if you are using electronic equipment and other tools that require testing and set-up.

- Think through the details and be prepared with a contingency plan. For example, in case there is no electricity to use an LCD projector, charts could be used.

\section{MATERIALS NEEDED}

Material needed for each session may vary, so make list of all the materials needed for each session and keep them ready. Generally, materials include:

- Registration forms

- Name tags

- Flip charts (some pages blank, some pre-populated)

- Markers

- Flash cards

- Post-its

- Sticking tape

- Handouts

- LCD projector and screen

- Laptop

- Writing pads and pens 


\section{INITIATING THE WORKSHOP}

The following time could be adopted for initiating the workshop:

\begin{tabular}{|l|l|l|}
\hline Session & Title & Duration \\
\hline 1 & Welcome and introduction & 30 minutes \\
\hline 2 & Expectations of the workshop & 15 minutes \\
\hline 3 & Pretest & 15 minutes \\
\hline
\end{tabular}

- Welcome the participants and facilitate introductions. For example, pair up participants and ask them to introduce themselves to each other, including their name, designation, their town or organization, years of experience, and their role in M\&E. Have each pair stand up and introduce each other to the rest of participants.

- Give each participant a copy of the workshop agenda to review. Ask participants to write their expectations of the workshop on cards or Post-its, put them up for all to see, and read them out. Allow participants to clarify their questions, if any.

- Administer the pretest questionnaire. Explain to participants the purpose of a pretest. This is not to assess individuals' knowledge, but to assess collective knowledge so that facilitators can focus on addressing the knowledge gaps.

- For group activities, create small groups so people are more comfortable talking and interacting. Mix up different types of people in each group.

- Choose one volunteer from the group to keep time and facilitate discussion, and another volunteer to report to all the participants.

- Determine how you'll record the ideas from each group. Will participants shout them out while you write them down? Or will they write down their own ideas and then give them to you? This is a small, but important, detail that is often overlooked.

- Start the meeting with a few icebreakers to get everyone relaxed and comfortable.

- After the first day, begin each day with a brief overview of what was covered the previous day. Assign a volunteer or two each day or for each session to provide this recap.

\section{ENERGIZERS}

Games build enthusiasm and help participants to relax. Use energizers frequently during the workshop. Choose games that are appropriate for the local context in which everyone can participate. Select short energizers and move on to the agenda of the workshop quickly. Some examples of energizers follow:

- Match the cards: On blank index cards, draw a number of objects so that one card has one apple, a second card has two apples, and so on. On another set of cards write a number (1, 2, and so on). Mix up all the cards. Distribute to participants and ask each participant to find the person who has the matching number. For example, someone with two apples on their card has to find a partner who has a card with " 2 "' written on it. This game can also be used to make groups like all having even numbers together and all having odds numbers together.

- Invite to sit: Have a few participants sit in a circle and ask them to reserve a seat on their right. Ask those who are seated to call one of the standing participants to invite them to sit in the reserved seat saying a reason, for example, "Manoj, please come. Today is my birthday."

- Birthday gang: Ask participants to stand up and group together according to the month they were born. Count the members in the each group and tell everyone about the size of the groups. Then, ask everyone to regroup according to the date they were born. Count the members in those groups and talk about the change in the size of the groups. 
- Chain of words: Say any two words out loud. Ask the first participant to say those two words and add one word of his or her own. All other participants repeat the last two words said out loud and one word of their own.

\section{CLOSING THE WORKSHOP}

- Administer the posttest questionnaire. Explain to participants the purpose of a posttest. This is not to assess individuals' gain in knowledge, but to assess collective gain in knowledge and identify gaps, if any.

- Tell participants about future courses of action, if any, and allow time for clarifications. Ask participants to write their reflections about the course and their commitments. Put them up and read them aloud. 


\section{MODULE 1}

\section{BASICS OF SOCIAL AND BEHAVIOR CHANGE COMMUNICATION}

Note: This module is mainly to be used with M\&E officials at the national and state level. The details given in this module may be reduced for district level health officers who are responsible for day-today program monitoring.

\section{LEARNING OBJECTIVES}

By the end of this session, participants will:

- Know the difference between Information, Education, and Communication (IEC) and Social and Behavior Change Communication (SBCC)

- Be familiar with various theories of behavior change

- Understand the Socio-Ecological Model for Change

Total Time: 1 hour, 30 minutes

\section{OVERVIEW}

\begin{tabular}{|l|l|l|}
\hline Session & Title & Duration \\
\hline 1 & Difference Between IEC and SBCC and Theories of Behavior Change & 45 minutes \\
\hline 2 & Group Work and Presentation & 45 minutes \\
\hline
\end{tabular}

\section{MATERIALS NEEDED}

- Index cards or Post-its

- Flip charts (blank)

- Markers

- Handouts

- PowerPoint presentation and LCD projector 


\section{ADVANCE PREPARATION}

- Make copies of the handouts and PowerPoint slides.

\section{HANDOUTS}

- Participant's Handout \#1.1: Socio-ecological Model

- Participant's Handout \#1.2: Understanding What SBCC Can and Cannot Do

\section{INSTRUCTIONS}

\section{Session 1.1 Strategic Behavior Change Communication}

\section{5 minutes}

1.

Inform participants that this session will cover differences between IEC and SBCC and the evolution of theory of change model of communication programs.

2.

Distribute two different colored cards to each participant. On one color, ask participants to write their definition of IEC, and on the second card, ask them to write their definition of SBCC. Collect the cards and stick them on the wall using tape.

3. Ask participants to read the cards out loud and discuss the differences between IEC and SBCC.

4. Explain further the differences between IEC and SBCC using a PowerPoint presentation.

IEC to BCC to SBCC:

- SBCC has evolved from IEC and health education.

- Earlier models used a linear "expert-learner" or "sender-receiver" paradigm to transfer information.

- The focus then shifted to BCC, which emphasizes analysis of behaviors and determinants to affect changes in knowledge, attitudes, and practices.

- Now, our focus is SBCC, which employs a more comprehensive approach. It goes beyond individual behavior change to Designed to address 'tipping points' for change at individual, community, and social levels.

5.

Use the PowerPoint presentation to orient participants on the evolution of theory of behavior change to the current socio-ecological model of change. 
6. Give Handout \#1.1 to participants while explaining the socio-ecological model of behavior change.
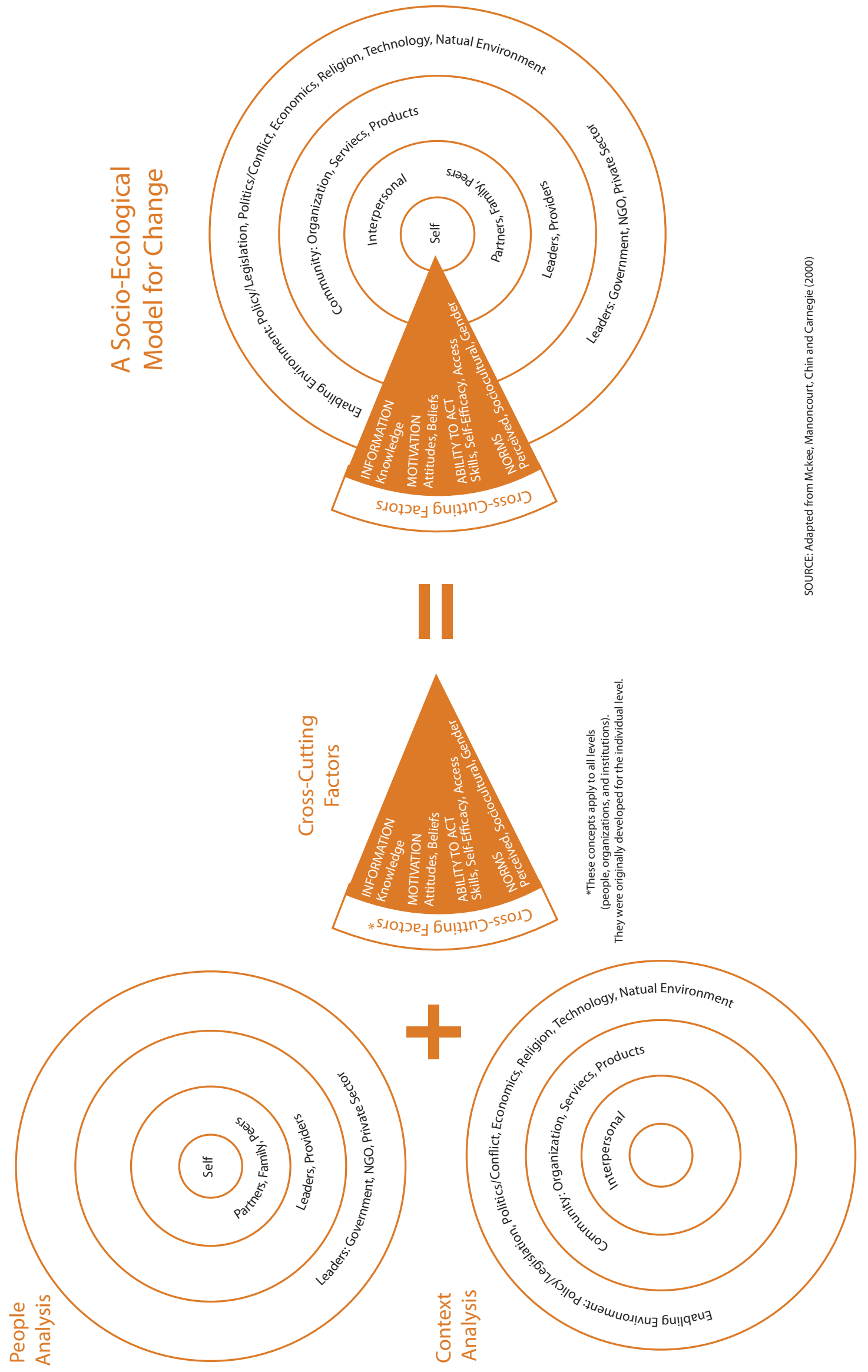
Participant's Handout \#1.2: Understanding What SBCC Can and Cannot Do

\begin{tabular}{|c|c|}
\hline SBCC Can & SBCC Cannot \\
\hline $\begin{array}{l}\text { Information } \\
\text { Increase knowledge and awareness of an issue, } \\
\text { Counter myths and misconceptions } \\
\text { Motivation } \\
\text { Influence perceptions, beliefs, and attitudes that may } \\
\text { change social norms } \\
\text { Show the benefit of behavior change } \\
\text { Prompt action } \\
\text { Trigger an individual to adopt and maintain a new } \\
\text { health behavior } \\
\text { Ability to Act } \\
\text { Demonstrate and provide an opportunity to practice } \\
\text { skills } \\
\text { Reinforce self- and collective-efficacy } \\
\text { Strengthen organizational and network relationships } \\
\text { Address barriers and systemic problems, such as } \\
\text { insufficient access to care, through advocacy and } \\
\text { mobilization } \\
\text { Norms Change } \\
\text { Support or initiate norm change } \\
\text { Mobilize community members or whole social } \\
\text { movements } \\
\text { Advocate for a health or development issue or policy } \\
\text { Initiate adoption of a new policy direction }\end{array}$ & $\begin{array}{l}\text { Compensate for inadequate infrastructure or logistics } \\
\text { of services, lack of access to them, or policies regulating } \\
\text { them } \\
\text { It can, however, mobilize or advocate for an } \\
\text { improvement in these areas. } \\
\text { Produce sustainable change without the support } \\
\text { of other program components or whole programs } \\
\text { providing services, providing technology, and } \\
\text { enforcing regulations and policies } \\
\text { It can, however, link with these programs and } \\
\text { make their work visible. } \\
\text { Be equally effective in addressing issues in different } \\
\text { countries with cookie-cutter strategies } \\
\text { It can, however, provide how-to tools and } \\
\text { guidelines for adaptation and tailoring toward } \\
\text { specific audiences and their existing assets or } \\
\text { barriers to change. }\end{array}$ \\
\hline
\end{tabular}

7. Keep the following points in mind for concluding the discussion of the socio-ecological model of behavior change.

\section{Socio-ecological model of behavior change:}

- Is the systematic application of interactive, theory-based, and research-driven communication processes and strategies to address change at individual, community, and societal levels.

- Is a process: Understanding the situation, focusing and designing the strategy, creating interventions and materials, implementing and monitoring, and evaluating and re-planning

- Examines people and domain of influence, information, motivation, ability to act and norms

- Operates through three key strategies: advocacy, social mobilization, and BCC 


\section{Session 1.2 Group Work: Socio-ecological Model}

\section{5 minutes}

1.

Divide the participants into three groups of 7-8 persons. Ask them to develop a socioecological model for the following three issues and to present and discuss the model with the larger group:

- Group 1: Increase child delivery in an institutional setting

- Group 2: Increase postnatal care for mothers and newborns

- Group 3: Increase use of family planning (FP) methods among young people

2. Ask participants if they have any questions and conclude the session.

In summary, SBCC:

- Has evolved from IEC and BCC and employs a more comprehensive approach

- Reinforces self- and collective-efficacy for behavior change

- Is the systematic application of interactive theory- and research-driven communication processes and strategies that address change at individual, community, and societal levels

- Is a process, uses a socio-ecological model, and operates through three key strategiesadvocacy, social mobilization, and BCC

\section{REFERENCES}

Bandura, A., C. Pastorelli, C. Barbaranelli, and G.V. Caprara. 1999. Self-Efficacy Pathways to Childhood Depression. Journal of Personal and Social Psychology, 76:2, pp. 258-269.

Janz, N.K., and M.H. Becker. 1984. The Health Belief Model: A Decade Later. Health Education Quarterly, 11:1 (Review), pp.1-47.

Ajzen, I. (1991). The theory of planned behavior. Organizational Behavior and Human Decision Processes, 50, p. 179-211.

Kelly, J. 1995. Changing HIV Risk Behavior: Practical Strategies. The Guilford Press, New York.

McKee, N., Manoncourt, E., Chin, S.Y. and Carnegie, R. (eds.). 2000. Involving People, Evolving Behavior. New York: UNICEF, Penang, Malaysia: Southbound.

Rosenstock, I. M., V.J. Strecher, and M.H. Becker. 1988. Social Learning Theory and the Health Belief Model. Health Education Quarterly, 15, pp. 175-183. 


\section{MODULE 2}

\section{INTRODUCTION TO MONITORING AND EVALUATION}

Note: This module is applicable for M\&E capacity building specific to understanding basics of M\&E at all three levels (national and state level officers who will act as master trainers, state level health officers who are mainly managers, and district level health officers who are responsible for day-today implementation and monitoring of the program and expect to make evidence-based decisions to improve program performance).

\section{Learning Objectives}

By the end of this module, participants will be able to:

- Define monitoring and evaluation and explain how they differ

- Describe types of indicators

- Identify characteristics of good indicators

\section{Total Time: 1 hour, 45 minutes}

\section{OVERVIEW}

\begin{tabular}{|l|l|l|}
\hline Session & Title & Duration \\
\hline 1 & Monitoring and Evaluation and Types of Indicators & 60 minutes \\
\hline 2 & Group Work and Presentation & 45 minutes \\
\hline
\end{tabular}

\section{MATERIALS NEEDED}

- Flip chart paper (some pages blank, some pre-populated)

- Markers

- Participant handouts, including hard copies of PowerPoint presentation

- LCD projector (if available) 


\section{ADVANCE PREPARATION}

- Make copies of the participant handout and PowerPoint slides or flip chart

\section{HANDOUTS}

- Participant's Handout \#2.1: List of Indicators

\section{Session 2.1:Monitoring and Evaluation and Types of Indicators}

\section{0 minutes}

\section{INSTRUCTIONS}

1. Congratulate participants for completing Module 1 on the Basics of SBCC. Explain that you will now discuss on monitoring and evaluation.

2.

Refer to a pre-populated flip chart page or PowerPoint slide and explain monitoring and evaluation (about 10 minutes). Remember the following points:

\section{Monitoring:}

- Tracks changes in program performance over time against measurable indicators

- Is a continuous process of checking and analyzing the implementation process

- Involves routine data collection of both quantitative and qualitative measures

- Informs stakeholders about the progress thus, facilitating informed decision making during implementation

\section{Evaluation:}

- Attempts to determine the relevance, effectiveness, and impact of activities in relation to the intended objectives

- Can be conducted during or at the end of the project and measured against baseline indicators

- Can estimate the reach, diffusion effects, and process of behavior change

- Involves data collection of both quantitative and qualitative measures

3. Refer to a pre-populated flip chart page or PowerPoint slide and explain indicators (about 15 minutes). Remember the following points: 
Indicators:

- Measure the communication outputs and outcomes provided through different channels such as interpersonal communication (IPC), mid-media, or mass media

- Can be defined to give both quantitative and qualitative measurements

- Must be defined according to the activities during the planning process of the program

There are two types of monitoring indicators: process and output.

- Process indicators help to assess how the planned activities have been implemented both with respect to time schedule and quality of the implementation.

- Output indicators measure the extent to which the planned activities have actually been implemented.

There are also two types of evaluation indicators: outcome and impact.

- Outcome indicators measure the outcomes that the SBCC program hopes to achieve, which are identified in the communication objectives. These are intermediate results of the impact, which is the ultimate objective of the program.

- Impact indicators measure the long-term effects, or end results, of the SBCC program. These indicators may not be achieved during the life of the project, depending on the project's length. Evaluation of a short-duration campaign may not capture these indicators.

4.

Distribute the handout\#2.1 to participants and ask a few participants to identify whether the given indicators are process indicator, output indicator, outcome indicator, or impact indicator? (about 10 minutes)

\section{Participant Handout \#2.1: List of Indicators}

\begin{tabular}{|c|c|}
\hline Indicator & $\begin{array}{l}\text { Types of } \\
\text { Indicator }\end{array}$ \\
\hline 1. Three nukkadnatak team for $\mathrm{MCH}$ health messages developed & \\
\hline 2. Two TV MCH health message advertisements developed & \\
\hline 3. Change in neonatal mortality rate in intervention area & \\
\hline 4. Percentage of non-pregnant women using modern contraceptive methods & \\
\hline 5. Three radio $\mathrm{MCH}$ health message advertisements developed & \\
\hline 6. $50 \mathrm{MCH}$ health message posters posted in each Gram Panchayat & \\
\hline 7. 3,500 pregnant women contacted by ASHAs in 100 Gram Panchayats & \\
\hline 8. Three nukkadnatak on MCH shown in 100 Gram Panchayats in 3 months & \\
\hline 9. Percentage of mothers advised on post-partum care by trained peer educators & \\
\hline 10. 500 peer educators trained on $\mathrm{MCH}$ health message in 100 Gram Panchayats & \\
\hline
\end{tabular}
appropriate indicators (about 10 minutes). 
Appropriate M\&E questions about the communication objectives and work plan for the SBCC can be helpful in developing appropriate indicators, as shown in the examples below.

\begin{tabular}{|c|c|c|}
\hline $\begin{array}{l}\text { Communication Objective } \\
\text { and Work Plan Activity }\end{array}$ & Monitoring Questions & Monitoring (Process/Output) Indicators \\
\hline $\begin{array}{l}\text { Objective: By end of project, } \\
\text { there will be an } X \text { percent } \\
\text { increase in the number of } \\
\text { women who are aware of the } \\
\text { benefits of family planning }\end{array}$ & $\begin{array}{l}\text { Was the radio spot aired? } \\
\text { How often was it aired? } \\
\text { At what time? } \\
\text { In how many communities? }\end{array}$ & $\begin{array}{l}\text { Process indicator: Number of times radio spot aired, } \\
\text { dates/times radio spot aired, number of communities } \\
\text { in which radio spot aired } \\
\text { Output indicator: Number of community members/ } \\
\text { target audiences that heard the radio spot }\end{array}$ \\
\hline \multirow{2}{*}{$\begin{array}{l}\text { Activity: Air a radio spot in } \\
\text { three communities }\end{array}$} & Evaluation Question & Evaluation (Outcome) Indicators \\
\hline & $\begin{array}{l}\text { Did women become more } \\
\text { aware of the benefits of family } \\
\text { planning? }\end{array}$ & $\begin{array}{l}\text { Increase in the percentage of women aware of } \\
\text { benefits of family planning as compared to baseline } \\
\text { or the difference in awareness between those who } \\
\text { heard and those who did not hear the radio spots }\end{array}$ \\
\hline
\end{tabular}

6.

Refer to a pre-populated flip chart page or PowerPoint slide and explain characteristics of indicators with a given example (about 10 minutes). Remember the following points:

\section{A good indicator must follow the SMART criteria:}

- Specific-Clearly written to avoid differing interpretations

- Measurable-Allows for monitoring and evaluating progress toward achieving the result

- Appropriate- Matches the scope of your program or work activities, so that you can influence or make changes

- Realistic - Is achievable within the time allowed

- Time bound-Includes a specific time period

Example of a SMART objective: 15 percent increase in institutional deliveries in the 25 intervention districts of Uttar Pradesh through the SBCC program in next 3 years

7.

Say, as a general guide, 5 to 10 percent of a program's budget should go toward M\&E for effective M\&E of program.

8. Ask participants if they have any questions. (about 5 minutes)

\section{Session 2.2: Group Work and Presentation}

\section{5 minutes}

\section{INSTRUCTIONS}

1. Make three groups of 6-7 people and give each group an issue discussed in the first module.

- Group 1: Increase child delivery in an institutional setting 
- Group 2: Increase postnatal care for mothers and newborns

- Group 3: Increase use of Family Planning (FP) methods among young people

2. Ask each group to discuss the issue in their group and write down at least four monitoring and two evaluation indicators on the flip chart (20 minutes).

3. Ask each group to present their indicators using the flip chart. After the presentations, open the floor for discussion and summarize feedback by the group ( 8 minutes each group).

\section{REFERENCES}

Frankel, N. and Gage, A. 2007. M\&E Fundamentals: A Self-Guided Minicourse, MEASURE Evaluation

S. Change. 2012. C Modules: A Learning Package for Social and Behaviour Change Communication (SBCC). Washington, DC: C-Change/FHI 360

Williams, K. and Ramarao, S. 2009. A Manual for Monitoring and Evaluation of Service Delivery Programs, Population Council

Reitbergen-McCracken J, Narayan D. Participation and Social Assessment: Tools and Techniques. Washington, DC: World Bank; 1998. Available at: http://www.worldbank.org/poverty/impact/ resources/toolkit.pdf. 


\section{MODULE 3}

\section{MONITORING AND EVALUATION OF SBCC PROGRAMS THROUGH A LOGICAL FRAMEWORK MATRIX}

Note: This module is applicable for M\&E officials at all levels (national, state, and district).

\section{Learning Objectives}

By the end of this session, participants will be able to:

- Describe a Logical Framework Matrix and how it helps in monitoring and evaluating SBCC programs

- Develop a Logical Framework Matrix

Total Time: 1 hour, 45 minutes

\section{OVERVIEW}

\begin{tabular}{|l|l|c|}
\hline Session & Title & Duration \\
\hline 1 & Introduction to Logical Framework Matrix & 45 minutes \\
\hline 2 & Group Work and Presentation & 60 minutes \\
\hline
\end{tabular}

\section{MATERIALS NEEDED}

- Flip charts (blank)

- Markers

- Handouts

- PowerPoint presentation and LCD projector

\section{ADVANCE PREPARATION}

- Make copies of the handouts and PowerPoint slides. 


\section{HANDOUTS}

- Participant's Handout \#3.1: Logical Framework Matrix

\section{SESSION 3.1}

\section{5 minutes}

\section{INSTRUCTIONS}

1. Ask participants what they understand about the Logical Framework Matrix (Logframe). Write down the responses on the flip chart. Acknowledge all responses and reinforce those that are correct about the logframe.

2. Introduce the Logframe using a PowerPoint presentation.

3. Distribute participant's handout \#3.1.

Participant's Handout \#3.1: Logical Framework Matrix

\begin{tabular}{|c|c|c|c|c|c|}
\hline $\begin{array}{l}\text { Intervention } \\
\text { Logic }\end{array}$ & $\begin{array}{l}\text { Objectively } \\
\text { Verifiable } \\
\text { Indicators of } \\
\text { Achievement }\end{array}$ & Timeline & $\begin{array}{l}\text { Person(s) } \\
\text { Responsible }\end{array}$ & $\begin{array}{l}\text { Sources and } \\
\text { Means of } \\
\text { Verification }\end{array}$ & Assumptions \\
\hline Goal: & Impact: & & & & \\
\hline Objective: & Outcome: & & & & \\
\hline Activities: & Output: & & & & \\
\hline Inputs: & & & & & \\
\hline
\end{tabular}

4. Explain the vertical logic and the horizontal logic of the logframe. Keep the following points in mind while discussing the logframe:

Components of Logical Framework Matrix (Logframe):

- Goal: A high-level objective that the project is expected to achieve.

- Objectives: The effects as a result of which the goal is achieved.

- Activities: The actions that, when implemented within the given time period, will result in achieving the objectives.

- Inputs: Preparations made to implement an activity.

- Objectively verifiable indicators of achievement: Measurements used to assess the progress of intervention logic.

- Timeline: The time frame within which the activities are expected to be completed.

- Person(s) responsible: The person(s) expected to ensure the activity is done.

- Sources and means of verifying the indicators are key elements that will determine how M\&E will be done.

- Assumptions are external factors beyond the scope of the proposed project that are necessary to effectively implement the activities and achieve the objectives 
5. Use the following matrix as an example to explain the logframe for SBCC interventions.

\section{Example of a Logframe for SBCC}

\begin{tabular}{|c|c|c|c|c|c|}
\hline Intervention Logic & $\begin{array}{l}\text { Objectively Verifiable } \\
\text { Indicators of } \\
\text { Achievement }\end{array}$ & Timeline & $\begin{array}{l}\text { Person } \\
\text { Responsible }\end{array}$ & $\begin{array}{l}\text { Means of } \\
\text { Verification }\end{array}$ & Assumptions \\
\hline $\begin{array}{l}\text { Goal: Increase } \\
\text { contraceptive use in } 100 \\
\text { Gram Panchayats (GPs) of } \\
\text { one district }\end{array}$ & $\begin{array}{l}\text { Impact: Reduce unmet } \\
\text { need, increase Contraceptive } \\
\text { Prevalence Rate }\end{array}$ & $\begin{array}{l}\text { By the end } \\
\text { of project }\end{array}$ & & $\begin{array}{l}\text { Large-scale } \\
\text { surveys }\end{array}$ & \\
\hline $\begin{array}{l}\text { Objective: Increase use } \\
\text { of modern FP methods } \\
\text { through systematic SBCC }\end{array}$ & $\begin{array}{l}\text { Outcome: } \\
\text { Percent of women } \\
\text { reporting discussion with } \\
\text { husband/family for FP } \\
\text { Percent of women using } \\
\text { modern FP }\end{array}$ & $\begin{array}{l}\text { Start and } \\
\text { end of } \\
\text { project }\end{array}$ & & $\begin{array}{l}\text { Baseline } \\
\text { and endline } \\
\text { surveys }\end{array}$ & $\begin{array}{l}\text { Contraceptives } \\
\text { are made } \\
\text { available }\end{array}$ \\
\hline $\begin{array}{l}\text { Activities: } \\
\text { 1. Sensitization of } \\
\text { all government } \\
\text { department on the } \\
\text { SBCC strategy }\end{array}$ & $\begin{array}{l}\text { Output: } \\
\text { - A training on the SBCC } \\
\text { strategy for all concerned } \\
\text { government departments }\end{array}$ & July 2014 & Designation & $\begin{array}{l}\text { Project } \\
\text { progress } \\
\text { report }\end{array}$ & $\begin{array}{l}\text { Fund release by } \\
\text { government is } \\
\text { timely }\end{array}$ \\
\hline $\begin{array}{l}\text { 2. SBCC activities } \\
\text { 2.1 SBCC materials } \\
\text { showed/displayed } \\
\text { 2.2 Training of ASHA in } \\
\text { FP counselling }\end{array}$ & $\begin{array}{l}10 \text { film shows organized in } \\
\text { each GP per month } \\
50 \text { posters distributed/ } \\
\text { displayed in each GP }\end{array}$ & $\begin{array}{l}\text { From Oct } \\
2014 \\
\text { Nov } 2014\end{array}$ & $\begin{array}{l}\text { Designation } \\
\text { Designation }\end{array}$ & $\begin{array}{l}\text { MIS } \\
\text { MIS } \\
\text { MIS }\end{array}$ & $\begin{array}{l}\text { ASHAs are } \\
\text { committed to } \\
\text { counselling } \\
\text { No natural } \\
\text { calamities }\end{array}$ \\
\hline $\begin{array}{l}\text { 3. Systematic M\&E plan } \\
\text { 3.1 Prepare an M\&E } \\
\text { framework } \\
\text { 3.2 Design MIS and key } \\
\text { indicators } \\
\text { 3.3 Baseline survey } \\
\text { 3.4 Endline survey }\end{array}$ & $\begin{array}{l}\text { - } \text { All ASHAs are trained } \\
\text { - M\&E framework developed } \\
\text { - } \text { operational } \\
\text { - Baseline report presented } \\
\text { - Endline report presented }\end{array}$ & $\begin{array}{l}\text { Nov } 2014 \\
\text { July } 2014 \\
\text { Sept } 2014 \\
\text { Oct } 2014 \\
\text { Oct } 2015\end{array}$ & $\begin{array}{l}\text { Designation } \\
\text { Designation } \\
\text { Designation } \\
\text { Designation } \\
\text { Designation }\end{array}$ & $\begin{array}{l}\text { Project } \\
\text { progress } \\
\text { report }\end{array}$ & \\
\hline $\begin{array}{l}\text { Inputs: } \\
\text { 1. Staff for the project } \\
\text { 2. Development of an } \\
\text { SBCC strategy } \\
\text { 3. Films and SBCC } \\
\text { materials developed/ } \\
\text { adopted } \\
\text { 4. Procurement of } \\
\text { projectors }\end{array}$ & $\begin{array}{l}\text { Staff for the project are } \\
\text { hired/identified } \\
\text { SBCC strategy developed } \\
2 \text { films,3 types of posters, } \\
\text { and counselling tool } \\
\text { developed/adopted } \\
100 \text { copies of films made, } \\
5,000 \text { poster printed, and } \\
500 \text { counselling tools } \\
\text { prepared } \\
10 \text { projectors purchased }\end{array}$ & $\begin{array}{l}\text { March } 2014 \\
\text { June } 2014 \\
\text { Sept } 2014 \\
\text { Sept } 2014 \\
\text { Sept } 2014\end{array}$ & $\begin{array}{l}\text { Designation } \\
\text { Designation } \\
\text { Designation }\end{array}$ & $\begin{array}{l}\begin{array}{l}\text { Project } \\
\text { progress } \\
\text { report }\end{array} \\
\text { Project } \\
\text { inventory } \\
\text { Project } \\
\text { progress } \\
\text { report }\end{array}$ & $\begin{array}{l}\text { Resources } \\
\text { required are } \\
\text { budgeted } \\
\text { Fund release by } \\
\text { government is } \\
\text { timely }\end{array}$ \\
\hline
\end{tabular}

\section{SESSION 3.2}

\section{0 minutes}

\section{INSTRUCTIONS}

1. Divide the participants into three groups of 6-7 persons. Ask each group to develop a logframe using the flip chart based on participant's handout \#3.1, Provide one of 
the following communication objectives to each group. Allot 30 minutes for this exercise.

- Group 1: Increase knowledge among families about benefits of institutional delivery

- Group 2: Promote awareness among women about early and exclusive breastfeeding

- Group 3: Increase the risk perception of families if their children are not fully immunized

2. Ask each group to make the presentation on the logframe they developed and share their experience in developing logframe (each team about 8 minutes)

3. Conclude this session using the following message:

\section{In summary:}

- The logframe is a tool for representing the project activities and expected results in a logical manner.

- The logframe forms the basis for designing methodology and tools for M\&E.

\section{REFERENCES}

1. ICTD project News Letter, July 2006. https://www.ipfm.in/Images/RBM\%20Newsletter.pdf.

2. The logical framework approach Hand book for objective oriented planning. http://www. norad.no/en/tools-and-publications/publications/publication?key=109408

3. A guide for developing a logical framework. Centre for International Development and Training University of Wolverhampton.

4. Meg Gawler, 2005. Logical framework analysis. WWF Standards of Conservation Project and Program Management. www.artemis-services.com/downloads/logical-framework.pdf

5. Handbook for logical frame work Analysis. Economic Planning Unit. Prime ministers department. http://www.epu.gov.my/c/document_library/get_file?uuid=2cc13468-db3a46a3-bf48-510fe348e282\&groupld=283545

6. Katherine Williams and SaumyaRamaRao 2009. A Mannual for Monitoring and Evaluation of Service Delivery Programs, Population Council. 


\section{MODULE 4}

\section{MONITORING OF SBCC PROGRAMS AT DISTRICT AND BLOCK LEVEL}

Note: Monitoring of SBCC at district and block levels should be based on the project logframe as described in Module 3. The activities given in the logframe would be the basis for developing the monitoring tools and checklists. Synthesis of the findings and appropriate feedback is essential for effective monitoring. The checklists shown here are examples and can be adapted to the program being implemented. This module is applicable for M\&E officials at all levels (national, state, and district).

\section{Learning Objectives}

By the end of this session, participants will be able to:

- Develop a checklist for monitoring quantity and quality of SBCC activities, synthesizing the findings, and providing feedback to improve program implementation

- Understand feedback system in SBCC programs

\section{Total Time: 2 hours}

\section{OVERVIEW}

\begin{tabular}{|l|l|l|}
\hline Session & Title & Duration \\
\hline 1 & Monitoring Checklists and Feedback Systems & 60 minutes \\
\hline 2 & Group Work and Presentation & 60 minutes \\
\hline
\end{tabular}

\section{MATERIALS NEEDED}

- Flip charts (blank)

- Markers

- PowerPoint presentation and LCD projector 


\section{ADVANCE PREPARATION}

- Make copies of handouts and PowerPoint slides.

\section{HANDOUTS}

- Participant's Handout \#4.1: SBCC Activity Report

- Participant's Handout \#4.2: Location Hunt Form

- Participant's Handout \#4.3: Checklist for Quality Assessment of Group Meeting Conducted by $\mathrm{CHW}$

- Participant's Handout \#4.4: Exit Interview Form

\section{Session 4.1: Monitoring Checklists and Feedback Systems}

\section{0 minutes}

\section{INSTRUCTIONS}

1. Using a PowerPoint presentation, discuss the checklist for monitoring SBCC activities and discuss the feedback mechanism.

2. Ask the participants to share their experience with the feedback system. Discuss the following key elements of a feedback system:

Key Elements of a Feedback System

- Feedback should be based on sound and structured assessment-for example, based on an analysis of data obtained from the checklists.

- Feedback can be verbal or written with key action points.

- Feedback should be given with a positive attitude to motivate and reduce future barriers. A negative attitude can make the worker defensive and damage the working relationship.

- Feedback should include a dialogue starting with the SBCC worker sharing their own strengths, weaknesses and challenges

- Feedback should be a regular and timely to improve performance.

3. Feedback to the worker responsible for SBCC activity is easier to provide in monthly review meetings in line with " $5 \mathrm{Ws}$ and $1 \mathrm{H}^{\prime}$-which denotes where, when, what, who, why, and how-if they maintain a standardized SBCC activity report.

\section{Session 4.2: Group Work and Presentation}

\section{0 minutes}




\section{INSTRUCTIONS}

1. Divide the participants into four groups of 5-6 persons.

2. Give participants handouts \#4.1, 4.2, 2, 4.3, and 4.4, and ask them to fill in the checklist for an SBCC activity on family planning. Ask the groups to modify the format, if needed and the checklist as they feel appropriate. Allot 30 minutes for this exercise.

3. Ask each group to present their outcome and discuss. Give each group about 10 minutes.

\section{Participant's Handout \#4.1: Location Hunt Form}

\begin{tabular}{|l|l|}
\hline \multicolumn{2}{|l|}{ District: Block: } \\
\hline Village name: & Mobile number: \\
\hline Name of ASHA: & Mobile number: \\
\hline Name of ANM: & Mobile number: \\
\hline Name of Sarpanch: & Mobile number: \\
\hline VHSC representative: & Time: \\
\hline Approximate population of village: & \\
\hline Suitable location for play/screening the film: &
\end{tabular}

Participant's Handout \#4.2: Checklist for Quality Assessment of Group Meeting Conducted by $\mathrm{CHW}$

\begin{tabular}{|c|c|c|}
\hline No & Observations & Yes \\
\hline 1 & $\begin{array}{l}\text { CHW reached the place of group meeting before the scheduled time and made required ar- } \\
\text { rangements (e.g., setting up posters, counseling aids). }\end{array}$ & \\
\hline 2 & CHW greeted all participants. & \\
\hline 3 & CHW welcomed those who joined late. & \\
\hline 4 & CHW made sure all women were seated so that they could see the visuals or demonstrations. & \\
\hline 5 & CHW showed the given flip chart while communicating. & \\
\hline 6 & CHW demonstrated the given family planning models. & \\
\hline 7 & The audiovisual shown could be heard well. & \\
\hline 8 & CHW discussed all types of FP methods available. & \\
\hline 9 & The information given by $\mathrm{CHW}$ was technically correct. & \\
\hline 10 & CHW engaged audiences by asking open-ended questions. & \\
\hline 11 & CHW allowed and encouraged participants to ask questions. & \\
\hline 12 & CHW clarified questions raised by audiences in a non-judgmental manner. & \\
\hline 13 & CHW was honest while clarifying questions. & \\
\hline 14 & CHW summarized/reinforced key messages before ending the session. & \\
\hline 15 & CHW thanked all participants. & \\
\hline
\end{tabular}


Participant's Handout \#4.3: Exit Interview Form

\begin{tabular}{|c|c|c|}
\hline 1. & Date: & \\
\hline 2. & Village Name: & 3. GP Name: \\
\hline 3. & Name of respondent: & 6. Sex (M/F/other): \\
\hline 7. & BPL HH (Yes/No): & \\
\hline & Questions & Answers \\
\hline 8. & What is the theme of the play/film? & \\
\hline 9. & Have you ever heard of the theme(s) & Yes..............................1 Where: \\
\hline & before this show? & No................................. \\
\hline 10. & Can you mention 5 things you remember & 1. \\
\hline & from the play/film? & 2. \\
\hline & & 3. \\
\hline & & 4. \\
\hline & & 5. \\
\hline 11. & Would you like to use any services shown & 1. Antenatal care ..... \\
\hline & in the play/film? If yes, which services? & 2. Delivery............................. \\
\hline & & 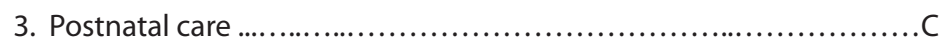 \\
\hline & & 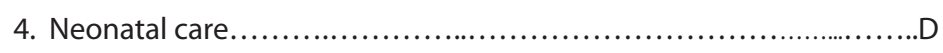 \\
\hline & & 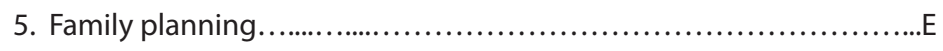 \\
\hline & & 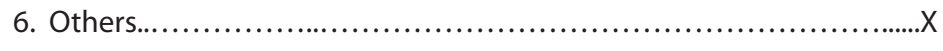 \\
\hline & & 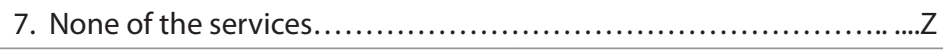 \\
\hline 12. & Would you like to share today's learning & 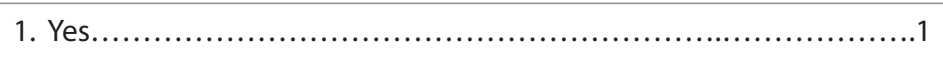 \\
\hline & with others (peer group or family)? & 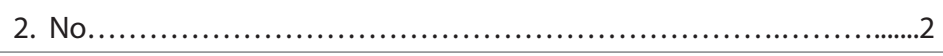 \\
\hline 13. & Mention 3 things you liked about the & 1. \\
\hline & play/film. & 2. \\
\hline & & 3. \\
\hline 14. & Mention 3 things to improve the play/ & 1. \\
\hline & film. & 2. \\
\hline & & 3. \\
\hline
\end{tabular}

Participant's Handout \#4.4. SBCC Activity Report

\begin{tabular}{|c|c|c|c|c|c|c|c|c|c|c|c|}
\hline \multicolumn{6}{|c|}{ Name of worker responsible for SBCC activity: } & \multicolumn{6}{|c|}{ Name of supervisor: } \\
\hline \multicolumn{6}{|l|}{ District: } & \multicolumn{6}{|c|}{ Block: } \\
\hline \multicolumn{6}{|c|}{ Gram Panchayat: } & \multicolumn{6}{|c|}{ Date (day/month/year): } \\
\hline \multirow{2}{*}{ 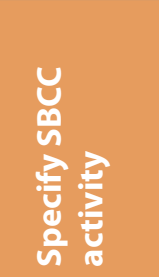 } & \multirow[b]{2}{*}{ 。 } & \multirow[b]{2}{*}{$\stackrel{\Xi}{E}$} & \multirow[b]{2}{*}{ 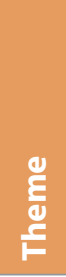 } & \multirow{2}{*}{ 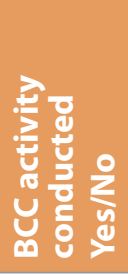 } & \multirow{2}{*}{ 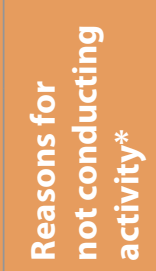 } & \multicolumn{3}{|c|}{$\begin{array}{l}\text { Number of Adults } \\
19-49\end{array}$} & \multirow{2}{*}{$\begin{array}{l}\frac{u}{v} \\
\frac{5}{d} \\
\frac{5}{0} \\
\frac{0}{2} \\
\text { U }\end{array}$} & \multirow{2}{*}{ 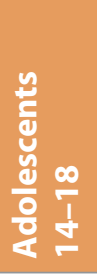 } & \multirow{2}{*}{ 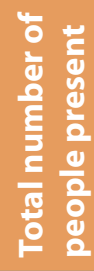 } \\
\hline & & & & & & $\frac{0}{\Sigma}$ & है & ㅎํㄹ & & & \\
\hline 1. Film shon & & & & & & & & & & & \\
\hline \multicolumn{12}{|l|}{$\begin{array}{l}\text { 2. Street } \\
\text { show }\end{array}$} \\
\hline \multicolumn{12}{|l|}{$\begin{array}{l}\text { 3. Group } \\
\text { meeting }\end{array}$} \\
\hline \multicolumn{12}{|l|}{$\begin{array}{l}\text { 4. IEC } \\
\text { materials } \\
\text { distribution }\end{array}$} \\
\hline TOTAL & & NA & NA & & NA & & & & & & \\
\hline
\end{tabular}




\section{MODULE 5}

\section{RESEARCH DESIGNS FOR EVALUATING SBCC PROGRAMS}

Note: This module about M\&E capacity building specific to understanding research designs for evaluating SBCC program is applicable to national- and state-level officers who will act as master trainers and to state-level health officers who are mainly managers. This will not be applicable for district health officers who are responsible for implementation and day-to-day program monitoring program.

\section{Learning Objectives}

By the end of this module, participants will understand:

- Why and what to evaluate in SBCC health interventions

- Research designs to evaluate SBCC health interventions

- How to select a research design

\section{Total Time: 3 hours}

\section{OVERVIEW}

\begin{tabular}{|l|l|c|}
\hline Session & Title & Duration \\
\hline 1 & Why and What to Evaluate in SBCC Health Interventions & 30 \\
\hline 2 & Research Designs to Evaluate SBCC Health Interventions & 60 \\
\hline 3 & Group Work and Presentation & 60 \\
\hline 4 & How to Select a Research Design & 30 \\
\hline
\end{tabular}

\section{MATERIALS NEEDED}

- Flip chart paper (some pages blank, some pre-populated)

- Markers

- Participant handouts, including hard copies of PowerPoint presentation and pretests

- LCD projector (if available) 


\section{ADVANCE PREPARATION}

- Make copies of handouts and PowerPoint slides.

\section{HANDOUTS}

- Participant's Handout \#5.1: Evaluation of Mobile Phone Intervention

- Participant's Handout \#5.2: Radio Program for Young Children Aged 11-14 (Case 1)

- Participant's Handout \#5.3 Diarrhea Management Program for Poor Family (Case 2)

- Participant's Handout \#5.4: BCC Intervention for Increasing Postpartum Contraception Among Women (Case 3)

\section{Session 5.1: Why and What to Evaluate in SBCC Health Interventions?}

\section{0 minutes}

\section{INSTRUCTIONS}

1.

Congratulate participants for completing Module 4.

2.

Explain to participants that you will now briefly discuss the purpose of evaluation in SBCC programs.

3.

Refer to a pre-populated flip chart page or PowerPoint slide and explain why and what to evaluate in SBCC health interventions? Remember the following points:

\section{Conduct evaluation to:}

- Determine if project goals, objectives, and intended outcomes are met and how the implementation challenges are met

- Assess the quality of the campaign in term of appropriateness of the message given in the local context, scheduling, reach, and recall

- Identify constraints and areas for improvement and suggest a course of action

- Analyze the cost of the intervention implemented and assess the cost of scaling up

- Communicate and advocate for the learning and results of the program

- Explore the possibility of scaling up to larger areas and or other areas 


\section{0 minutes}

\section{INSTRUCTIONS}

1. Explain to participants that we will now discuss on research designs for evaluating SBCC program. Say, in this module we will briefly discuss about research designs. For detailed understanding one can refer operations research handbooks.

2.

Say: The above communication intervention can be evaluated through different designs (experimental or non-experimental). Explain the different designs mentioned below by giving example of above intervention (about 30 minutes).

Note: You may choose to drop some designs based on audience need. For example, for state- and district-level training, experimental design would not be important, but time series design would be, as they gather a lots of MIS data. However, a national-level training audience would want to know all kinds of designs.

Some points to remember are:

\section{Non-experimental research designs:}

- Posttest-only design: Impact of an intervention is evaluated after it has been implemented for a specified period.

- Pretest-posttest design: Pre-intervention measurement of the outcome indicators are compared with post-intervention measurements.

- Post-experimental and control design: Post-experimental measurements of the outcome are compared with the measurements of the control group and not with the baseline measurements.

\section{Experimental research designs:}

- Pre-post experimental-control design, also called randomized control trial (RCT): Preand post-intervention measurements of the experimental group are compared with the corresponding measurements of the control group.

- Posttest-only control group design: Post-intervention measurements from experimental and control groups are compared assuming that the two groups were balanced at the beginning of the study.

\section{Quasi-experimental designs:}

- Non-equivalent experimental-control group design: Similar to the RCT design except the random allocation of subjects is not done in experimental and control groups.

- Time series design:Measures the outcomes at several points both before and after intervention and helps in understanding temporary gain well as the long-term impact of the program. It does not include a control group. 
Conditions other than the program that could be responsible for observed net outcomes in research designs (threats to validity):

Typically, an experimental design is planned to protect the findings from various conditions other than the program, such as those below, that could be responsible for observed net outcomes, also called threats to validity.

- History: Unplanned events that occur during the project that could influence the intended outcomes of the project.

- Selection: People selected for the control group differ greatly from the people selected for the experimental group.

- Maturation: People change over time and become mature resulting in changes that are independent of the changes the intervention is designed to produce.

- Mortality: Loss of participants to follow-up over time (cohort studies)

- Testing: Respondents interviewed again after some time answer some questions better because they gathered information from other sources that have nothing to do with intervention.

- Instrumentation: Changes in a study instrument (such as a questionnaire) occur between the pretest and posttest resulting in an effect that is independent of any effect due to experimentation.

4.

Refer to a pre-populated flip chart page or PowerPoint Slide and explain and a health intervention through information and communications technology (ICT). And ask participants to think about possible research designs to evaluate the following handout (about 15 minutes)

\section{Participant's Handout \#5.1}

Intervention: A health intervention planned for husbands to provide voice messages, approximately 15-20 seconds long, on their mobile phone once in a week over 12 months. The health information will end with a message encouraging husbands to discuss the information they heard with their wives and family members. Messages about the following topics will be given to husbands whose wives are in the third trimester of pregnancy:

- Three postnatal checkups for mother and newborn within 7 days of delivery

- Early initiation and exclusive breastfeeding

- Proper nutrition after 6 months

Evaluation of this program needs to measure knowledge and behavior change indicators related to the intervention, such as awareness about the importance of receiving three postnatal care (PNC) checkups for mother and newborn, family discussions initiated by the husband about the importance of early and exclusive breastfeeding, receipt of three PNC checkups (mother and child) within 7 days of delivery, initiation of breastfeeding within an hour of delivery, exclusive breastfeeding, and improved nutritional status of children.

Think about the above intervention and possible research design for evaluation which we will be discussing in this session. 


\section{0 minutes}

\section{INSTRUCTIONS}

1.

Make three groups of 6-7 people. Give each group a handout (\#5.1, 5.2, or 5.3) and flip chart. Ask each group to discuss the intervention program and suggest an appropriate research design in the flip chart (total time 30 minutes).

2. Ask each group to present their research design using the flip chart. After presentation, open the floor for discussion and summarize feedback by group (10 minutes each group).

Participant's Handout \#5.2

\section{Radio Program for Young Children Aged 11-14 (Case 1)}

Intervention: Meena Radio Program is being implemented in the state of Uttar Pradesh by UNICEF in partnership with the state government's Education Department. It reaches children 11-14 years of age studying in standard VI-VIII who listen to the broadcast during school hours. Through the popular cartoon character, Meena, the program covers a range of issues including child rights, child protection, child-friendly schools, gender, hygiene, and education. Integral to the program is the training provided to teachers on facilitating classroom discussions to explore and reinforce messages. The program was launched as a pilot in two districts in March 2010. It has since been scaled up and is currently being aired in more than 5,400 schools in nine districts across the state, and was heard by nearly 570,000 students in the last academic session.

Discuss the possible evaluation method for this intervention and suggest the evaluation design, tentative budget, and possible challenges.

Ref - http://www.unicef.org/rosa/media_2479.htm

\section{Participant's Handout \#5.3}

\section{Diarrhea Management Program for Poor Family (Case 2)}

Intervention: The diarrhea management program evolved over the years, from focusing on WHO formula oral rehydration solution (ORS) at inception, to covering all aspects of home-based diarrhea management, and eventually in 2007 to developing prototypes for introduction of Zinc therapy in the private sector in India. The program constantly upgraded objectives and strategies keeping in mind both public health needs and policy and technology shifts and was closely informed through intensive market research with consumers and providers at every step. In the second phase, the focus was on improving overall home diarrhea management practices with a specific focus on lower income households. This included improving correct knowledge and practices about ORS, feeding and breastfeeding practices, recognizing critical signs, and hand-washing.

The campaign applied an integrated marketing approach for promoting diarrhea management. It used a multipronged approach that included provider training, mass media advertising, consumer outreach activities, retail detailing and promotion, celebrity and partner activities, and innovations 
and large-scale mobilization around ORS day each year; a mix of media and activities was used by most large-scale consumer marketers.

\section{Discuss the possible evaluation method for the second phase of intervention and suggest the evaluation design, tentative budget, and possible challenges?}

Ref - SAATHI BACHPAN KE Promoting Diarrhea Management through the Private Sector in Urban North India

\section{Participant's Handout \#5.4}

BCC Intervention for Increasing Postpartum Contraception Among Women (Case 3)

Context: The Indian Family Planning Program, though success in increasing contraceptive use among couples who have achieved their desired family size, has not been equally successful in educating couples about the use of contraceptive methods for birth spacing.

Intervention: The intervention consisted of an educational campaign carried out by community workers. (No activities other than those of the government-run health program were conducted in the comparison areas.) Using communication materials (leaflets, posters, wall paintings, and booklets), workers educated all pregnant women registered for the study and their mother-in-law or the oldest female family member on healthy timing and spacing of pregnancy (first pregnancy should be delayed until age 18, women should wait at least 24 months after a live birth and 6 months after an abortion or miscarriage before planning their next pregnancy), postpartum care, the lactational amenorrhea method, and postpartum contraception. All educational materials and counseling aids were newly developed and pretested for their suitability for semiliterate women, the clarity of the messages, cultural acceptability, and familiar breast-mutation. All community workers received training in the topics covered by the intervention. The intervention was carried out between September 2006 and January 2007 among 959 pregnant women aged 15-24 who lived in Uttar Pradesh, India.

Discuss the possible evaluation method for this intervention and suggest the evaluation design, tentative budget, and possible challenges?

Ref - Sebastian M.P; Khan M.E et al. Increasing Postpartum Contraception in Rural India: Evaluation of a Community-Based Behavior Change Communication Intervention. International Perspectives on Sexual and Reproductive Health, 2012, 38(2)68-77

\section{Session 5.4: How to Select a Research Design}

\section{0 minutes}

\section{INSTRUCTIONS}

1.

Refer to a pre-populated flip charts page or PowerPoint slide and explain how to select a research design (about 30 minutes). Remember the following points:

\section{Selecting an appropriate research design:}

Selecting an appropriate research design depends on the research question, availability of funds, human resources, time constraints, and ethical considerations. It is always advised to start with the best and more rigorous design, but the local context and the constraints may force the use of a less 
rigorous design, compromising power and precision of the results. The researcher and his or her team are in the best position to choose the design most appropriate to the given context. However, the following rules of thumb suggested by Andrew et al. (1998) provide some guidance:

a) Whenever possible, try to create experimental and control groups by assigning cases randomly from a single population study group.

b) When random assignment is not possible, try to find a comparison group that is as nearly equivalent to the experimental group as possible.

c) When neither a randomly assigned control group nor a similar comparison group is available, try to use a time series design that can provide information on trends before and after a program intervention.

d) If a time series design cannot be used, at a minimum and before a program starts, try to obtain baseline (pretest) information that can be compared against post-program information (a pretest-posttest design).

e) If baseline (pretest) information is unavailable, be aware that you will be limited in the type of analysis you can conduct. You should consider using multivariate analytic techniques.

Always keep in mind the issue of validity. Are the measurements true? Do they do what they are supposed to do? Are there possible threats to validity (history, selection, testing, maturation, mortality, or instrumentation) that might explain the results?

Apart from the above technical issues, also consider the following:

- Availability of time and resource

- Advice of a statistician or a researcher well acquainted with design and sampling methods for the sample size calculation and finalization of design

Effect of sample size on cost (larger sample size means higher cost)

\section{REFERENCES}

Andrew A. Fisher et al., 1998 Handbook for Family Planning Operations Research Design Population Council

C4Change. 2012. C Modules: A Learning Package for Social and Behavior Change Communication (SBCC). Washington, DC: C-Change/FHI 360.

Stephen S Lim, Lalit Dandona, Joseph A Hoisington, Spencer L James, Margaret C Hogan, Emmanuela Gakidou 2010 Use of mass media campaigns to change health behavior Lancet 2010; 375: 2009-23 


\section{MODULE 6}

\section{USE OF QUALITATIVE METHODS IN MONITORING AND EVALUATING BEHAVIOR CHANGE COMMUNICATION}

Note: Qualitative research provides complementary data to the quantitative findings and helps to understand and to draw precise conclusions as to the "how" and "why" of human behavior. Qualitative research is also done independently as formative research prior to designing programs or quantitative data collection tools. In monitoring, qualitative methods help to learn the perception of audiences and stakeholders about the activities implemented. This module is meant to provide basic skills to M\&E officials at the national and state level. The details given in this module may be reduced for district-level health officers who are responsible for day-to-day program monitoring.

\section{Learning Objectives}

By the end of this session, participants will be able to explain:

- Qualitative research and how it differs from quantitative research

- The various qualitative data collection methods and their application in monitoring and evaluation of SBCC programs

\section{Total Time: 4 hours}

\section{OVERVIEW}

\begin{tabular}{|l|l|c|}
\hline Session & Title & Duration \\
\hline 2 & $\begin{array}{l}\text { Introduction to Qualitative Research } \\
\text { Qualitative Data Collection Methods: Observation and In- } \\
\text { depth Interviews and Their Application in SBCC }\end{array}$ & 45 minutes \\
\hline 3 & $\begin{array}{l}\text { Qualitative Data Collection Methods: Key Informant Inter- } \\
\text { views and Focus Group Discussions and Their Application } \\
\text { in SBCC }\end{array}$ & 45 minutes \\
\hline 4 & Group Work and Presentation & 75 minutes \\
\hline 5 & Sample Size Determination for Qualitative Studies & 30 minutes \\
\hline
\end{tabular}




\section{MATERIALS NEEDED}

- Index cards

- Flip charts

- Markers

- Handouts

- PowerPoint presentation and LCD projector

\section{ADVANCE PREPARATION}

- Make copies of the handouts and PowerPoint slides.

\section{HANDOUTS}

- Participant's Handout \#6.1: Case Study 1

- Participant's Handout \#6.2: Case Study 2

\section{Session 6.1: Introduction to Qualitative Research}

\section{5 minutes}

\section{INSTRUCTIONS}

1.

Explain what is qualitative research using a PowerPoint presentation. Points to remember follow:

\section{Qualitative research:}

- Is scientific research

- Aims to gather an in-depth understanding of the "how" and "why" of human behavior

- Complements and explains quantitative findings

- Can be done independently as a formative study or to assess quality of an implemented activity

2. Distribute two index cards to each participant. Ask them to write two differences between qualitative and quantitative research. Categorize them and read them out loud.

\begin{tabular}{|c|c|c|}
\hline Characteristics & Quantitative & Qualitative \\
\hline Analytical Objective & $\begin{array}{l}\text { - To quantify variation } \\
\text { - To describe the characteristics of a population } \\
\text { under study }\end{array}$ & $\begin{array}{l}\text { To describe variation } \\
\text { - To describe individual experiences and } \\
\text { group norms }\end{array}$ \\
\hline Question Format & $\begin{array}{l}\text { Closed-ended (select answers from options given) } \\
\text { or semi-structured }\end{array}$ & Open-ended (Answer is descriptive) \\
\hline Data Format & Gives results in numbers & Gives results in words \\
\hline Tool Design & $\begin{array}{l}\text { - Design of data collection tool design is stable } \\
\text { from beginning to end. } \\
\text { - Participants' responses do not influence or } \\
\text { determine how and which questions researcher } \\
\text { asks next; interviewer asks all questions and } \\
\text { follows the same order given in the questionnaire }\end{array}$ & $\begin{array}{l}\text { There is flexibility in the way questions } \\
\text { are asked } \\
\text { - Participants' responses affect how and } \\
\text { which questions researchers ask next; } \\
\text { order of questions is not important }\end{array}$ \\
\hline
\end{tabular}


3. Discuss the difference between qualitative and quantitative research using a PowerPoint presentation highlighting the following differences.

4. Conclude by discussing the need for qualitative methods using PowerPoint. Points to remember follow:

Qualitative methods help you to:

- Monitor and improve quality of the program implementation

- Understand participants' perspective not only about their behavior but also about the program and activities in which they have participated

- Explain quantitative results by exploring the reasons for the underlying behavior

- Develop options for answers and codes for quantitative questionnaires

Session 6.2: Qualitative Data Collection Methods: Observation and In-depth Interviews and Their Application in SBCC

\section{5 minutes}

\section{INSTRUCTIONS}

1. Introduce the types of qualitative data collection as given below.

Types of qualitative methods for monitoring and evaluation are:

- Observation as a qualitative tool

- In-depth interviews

- Key informant interviews

- Focus group discussions

1. Using a PowerPoint presentation, discuss the observation method and its uses.

3. Discuss the strengths and weakness of this method using the following table in a PowerPoint presentation.

\begin{tabular}{|l|l|}
\hline Strengths & Weaknesses \\
- Helps to understand contexts, relationships, and & $\begin{array}{l}\text { - Is time-consuming and costly } \\
\text { behaviors }\end{array}$ \\
- Can guide quality improvement of program & $\begin{array}{l}\text { Reporting of observations depends on researcher's } \\
\text { attention, memory, and personal discipline to note each } \\
\text { observation }\end{array}$ \\
implementation & $\begin{array}{l}\text { Dependent on the quality of checklist used for } \\
\text { observation }\end{array}$ \\
- Can provide new information that is crucial for project \\
design, data collection, and interpretation of other data \\
- Collection of observations can also be analyzed \\
quantitatively to give an overall perspective of program \\
implementation
\end{tabular}




\section{Points to remember:}

- Observations can be used to understand a behavior, for example, newborn care practices.

- Observations can be used to monitor the quality of implementation of an activity, for example, counseling by an ASHA using a flip chart.

4. Discuss in-depth interviews and their uses in this session using a PowerPoint presentation.

5. Discuss the strengths and weakness of this method using the following table in a PowerPoint presentation.

Strengths $\quad$ Weaknesses

- Provides more detailed information than what is - Interview takes more time and may require more than available through quantitative surveys one sitting with the informant

- Respondents more likely to feel free to talk when - Specially trained investigators are required interviewed one-on-one in a relaxed environment

\section{Points to remember:}

- In-depth interviews are useful for collecting data on personal histories, perspectives, and experiences, particularly on sensitive topics like reproductive behavior.

- Questions begin with "why" or "how," which gives informants freedom to answer.

- In-depth interviews may require interview of an individual more than once.

- In-depth interviews are recorded to complement the written notes developed as case studies.

- In-depth interviews with key stakeholders could be used to understand their perspectives about activities implemented.

6. Ask participants if they have any questions.

Session 6.3: Qualitative Data Collection Methods: Key Informant Interviews and Focus Group Discussions and Their Application in SBCC

\section{5 minutes}

\section{INSTRUCTIONS}

1. Discuss key informant interviews and its uses in this session using a PowerPoint presentation.

2. Discuss the strengths and weakness of this method using the following table in a PowerPoint presentation.

\begin{tabular}{|l|l|}
\hline Strengths & Weaknesses \\
\hline - Opportunity to get an insider's view & $\begin{array}{l}\text { Your relationship with the informant may influence the } \\
\text { information you get }\end{array}$ \\
$\begin{array}{l}\text { - Can provide in-depth information about the topic in a } \\
\text { short in-depth interview }\end{array}$ & $\begin{array}{l}\text { Informants may give their own impressions and biases } \\
\text { - Quick and cheap method of gathering information }\end{array}$ \\
& $\begin{array}{l}\text { Takes time to select good informants and build rapport } \\
\text { and trust }\end{array}$ \\
\hline
\end{tabular}




\section{Points to remember:}

- Key informants are persons who are believed to be a knowledgeable on the topic that the researcher wants to investigate.

- It is a quick and cheap method of gathering information

- Key Informant interviews can be done as a formative research for program planning as well as for developing quality assessment checklist for monitoring.

3. Discuss focus group discussions (FGDs) and their uses in this session using a PowerPoint presentation.

\section{Points to remember:}

- FGDs are effective in eliciting data on the cultural norms of a community.

- They generate broad overviews and perceptions of issues being discussed or about the activities implemented.

- They are effective in collecting different views on a specific topic from various participants in a short time.

- A large amount of information can be collected over a short period of time.

4. Ask the participants to say the key characteristics and steps involved in FGDs. Write them down on a flip chart. Ask if anyone has any alternate opinions and write them down on the flip chart. Now using a PowerPoint presentation discuss the key characteristics and steps involved in FGDs.

\section{Points to remember:}

- Held with a group of 6 to 10 participants.

- Participants are similar in characteristics like married young women, mothers-in-law, or adolescent girls $12-15$ years of age.

- Usually two researchers are needed to conduct an FGD: one researcher to ask questions and one researcher to take notes. Audio recording complements the notes taken.

- Well-planned, open-ended questions are used.

5. Discuss the strengths and weakness of this method using the following table in a PowerPoint presentation.

Strengths

- Participants can freely give information on the topic that are important to them but that the evaluator may not have anticipated.

- FGDs provide in-depth insights into how the participants feel about specific topics or an activity that was implemented. Group dynamics during the FGD reduces participants' inhibition about sharing feelings and stimulates discussion.

- FGDs take less time and cost compared to interviewing them individually.

- Findings are presented in narrative form, often with actual participant quotations that can help program leaders grasp participant's concerns and beliefs.

\section{Weaknesses}

The small number of respondents and the lack of random selection significantly limit the ability to generalize the findings to a larger population.

- The interaction of participants with the researchers and with each other may affect respondents' willingness to give differing opinions, particularly if the group is not homogeneous with respect to caste, class, and age profile.

- Respondents may hesitate to express their concerns in a group setting with peers or colleagues, but be more likely to express themselves in one-on-one interviews. 
6. Conclude with the following summary and ask participants if they have any questions.

In summary, qualitative research:

- Is scientific research that aims to gather an in-depth understanding of 'how' and 'why' of human behavior

- Complements and explains quantitative findings

- Can be done independently as a formative study or to assess quality of an implemented activity

\section{Session 6.4: Group Work and Presentation}

\section{5 minutes}

\section{INSTRUCTIONS}

1. Divide the participants into four groups. Give the following handouts to each group. Ask them to discuss and design a qualitative method to get information about the issue. Have each group present their results to the larger group.

\section{Participant's Handout \#6.1: Case Study 1}

Communication activity: The use of spacing methods among young women was low in Bihar due to myths and misconception regarding the side effects of IUD. It was also noted that the involvement of women in SHG meetings are high in the state. The Department of Health and Family Welfare in association with various SHGs initiated a SBCC program on awareness about the spacing method. In each SHG meeting half an hour was devoted for discussing the health issues and family planning use and ANM/ASHA provided information about various spacing methods by using video clips and leaflets. They also tried to dispel various myths associated with condom.

Question: What qualitative technique will be used to assess whether the video clipping was appropriate to convey the message and how effective were the sessions conducted by ASHA/ANM?

\section{Participant's Handout \#6.2: Case Study 2}

Communication activity: To promote male participation in family planning, the Rajasthan state health department puts up large posters and hoardings along the highway to Delhi in strategic locations such as eating joints. The posters address the benefits of using family planning methods with specific reference to condoms as a dual protection measure to prevent both pregnancy and sexually transmitted diseases. The health department wants to assess the effectiveness of locations where the messages are displayed.

Question: What qualitative technique would be best to assess appropriateness of the locations used to display the messages?

\section{Session 6.5: Sample Size Determination for Qualitative Studies}

\section{0 minutes}




\section{INSTRUCTIONS}

1. Discuss how to estimate sample size for qualitative studies. Points to remember are:

\begin{tabular}{|l|l|}
\hline Data Collection Method & Rule of Thumb \\
\hline Observation method & $\begin{array}{l}\text { Observe at least 2 episodes for each category of the } \\
\text { research question. For example, for counseling of women } \\
\text { and men on family planning, plan to observe at least 4ses- } \\
\text { sions (2 for women and 2 for men). }\end{array}$ \\
\hline In-depth interviews & $\begin{array}{l}\text { Select the persons highly recommended by the commu- } \\
\text { nity and who are knowledgeable about the topic under } \\
\text { investigation. Depending on the topic and purpose, inter- } \\
\text { view approximately 3-5 people. }\end{array}$ \\
\hline Focus groups & $\begin{array}{l}\text { Interview approximately 3-5 persons for each category in } \\
\text { the research question. For example, if interviewing moth- } \\
\text { ers with children younger than 6 months and children } \\
6-12 \text { months, plan to interview 5mothers in each group, } \\
\text { for a total of } 10 \text { mothers. }\end{array}$ \\
\hline $\begin{array}{l}\text { Interview approximately 2groups for each category in the } \\
\text { research question. For example, when studying males and } \\
\text { females of 3 different age groups, plan for 12focus groups } \\
\text { discussions. }\end{array}$ \\
\hline
\end{tabular}

Source: Adapted from a presentation by Dr. Bonnie Nastasi, https://my.laureate.net/Faculty/docs/.../qualit_res_smpl_size_consid.doc

2. Ask participants if they have any questions.

3. Ask participants how to develop the interview guidelines and discuss the following key points to remember:

- Ask open-ended questions rather than closed-ended. For example,

A Open-ended: "Please describe the services provided at the clinic" or "What are the main sources from which you seek information about health care?"

A Closed-ended: "Do you know about the services provided at the clinic?"

A Ask general questions first and then more specific questions.

- Ask positive questions before negative questions.

- Ask factual questions before opinion questions. For example, ask, "What activities were conducted?" before asking, "What did you think of the activities?"

- Ask follow-up questions about the views the informants give, such as:

A Would you please give me an example?

- Can you please describe that idea?

A Would you please explain that further?

I Is there anything more than this?

- Review the guide and eliminate any irrelevant questions.

\section{REFERENCES}

1. Qualitative Research Methods: A Data Collector's Field Guide. FHI 360, 2005.

2. Focus Group Facilitation Guidelines. Adapted from Centre for Higher Education Quality, Quality Advisor at Monash University

3. Evaluation of HIV prevention programs using qualitative Methods. Booklet 9. CDC

4. C-Change Module 5 (Facilitator), USAID

5. www.nucats.northwestern.edu/...research/.../Family_Health_International...区 


\section{MODULE 7}

\section{DEVELOPING TERMS OF REFERENCE FOR SBCC EVALUATION}

Note: Qualitative research provides complementary data to the quantitative findings and helps to understand and to draw precise conclusions as to the "how" and "why" of human behavior. Qualitative research is also done independently as formative research prior to designing programs or quantitative data collection tools. In monitoring, qualitative methods help to learn the perception of audiences and stakeholders about the activities implemented. This module is meant to provide basic skills to M\&E officials at the national and state level. The details given in this module may be reduced for district-level health officers who are responsible for day-to-day program monitoring.

\section{Total Time: 4 hours}

\section{Learning Objectives}

By the end of this session, participants will be able to:

- Develop Terms of Reference for an SBCC evaluation

- Prepare timeline for an evaluation

- Determine appropriate sample size

\section{OVERVIEW}

\begin{tabular}{|l|l|l|}
\hline $\begin{array}{l}\text { Ses- } \\
\text { sion }\end{array}$ & Title & Duration \\
\hline 1 & How to Develop Terms of Reference for SBCC Evaluation & 60 minutes \\
\hline 2 & Group Work and Presentation & 60 minutes \\
\hline 3 & Wrap-Up and Final Questions & 60 minutes \\
\hline
\end{tabular}

\section{MATERIALS NEEDED}

- Flip chart paper (some pages blank, some pre-populated) 
- Markers

- Participant's handouts, including hard copies of PowerPoint presentation (if applicable)

- LCD projector (if available)

\section{ADVANCE PREPARATION}

- Flip charts and/or PowerPoint presentation slides for this session

\section{HANDOUTS}

Participant's Handout \#7.1: Format for Timeline for the ToR of Evaluation

Participant's Handout \#7.2: Criteria for Scoring Potential Evaluators

\section{Session 7.1: How to Develop Terms of Reference for SBCC Evaluation}

Time: 60 minutes

\section{INSTRUCTIONS}

1.

Congratulate participants for completing Module 6. Explain to participants that we will now discuss Terms of Reference (ToR) for SBCC evaluation. Program managers who are involved in planning evaluations and commissioning consultancy services or other research institutions must know the key components that go in the ToR, which ensures that the study follows correct procedures and provides desired deliverables. (About 15 minutes).

2.

Refer to a pre-populated flip chart page or PowerPoint slide and explain ToR and how to develop a ToR for SBCC evaluation? (About 45 minutes). Remember the following points:

\section{Terms of Reference:}

- Forms the basis of a contractual agreement with the evaluators

- Describes the purpose and structure of conducting an evaluation by consultants or organizations

Following are key elements to include in the ToR:

- Background and rationale for the evaluation

- Objective of the evaluation

- Scope of the evaluation

A Include key evaluation questions that need to be answered with respect to relevance, effectiveness, and efficiency of the program.

^ Link evaluation questions directly to the main objective of the evaluation.

- Methodology for evaluation

- Roles and responsibilities

- Time schedule and reporting

- Budget

- Required qualifications of the evaluators

- Proposal submission rules and assessment criteria 
It is also advisable to provide a proposal outline in the ToR. Remember the following:

\section{Proposal Outline:}

- Cover Page - Project title; contact person's name and contact details; date of submission

- Executive Summary

- Context/Background (Understanding and need for the RFP)

- Methodology

- HR/Staffing Plan

- Budget (Brief budget allocation under line items)

- Personnel

- Travel

- Direct Costs and Indirect Costs/Overheads

- Appendices: CVs/briefbios of key team members

\section{Participant's Handout \#7.1: Format for Timeline of ToR for Evaluation}

\begin{tabular}{|c|c|c|c|c|c|c|c|c|c|}
\hline Activity & M1 & M2 & M3 & M4 & M5 & M6 & M7 & M8 & M9 \\
\hline \multicolumn{10}{|c|}{ Communication of ToR to listed agency or advertised } \\
\hline \multicolumn{10}{|l|}{ Deadline for proposals } \\
\hline \multicolumn{10}{|l|}{ Selection of an agency } \\
\hline \multicolumn{10}{|l|}{ Planning meeting to start evaluation } \\
\hline \multicolumn{10}{|l|}{ Data collection and analysis } \\
\hline \multicolumn{10}{|c|}{ Meetings between program and evaluating agency } \\
\hline \multicolumn{10}{|l|}{ Draft report } \\
\hline \multicolumn{10}{|c|}{ Feedback and meeting with Evaluation Steering Group } \\
\hline \multicolumn{10}{|l|}{ Final report } \\
\hline Presentation and discussion of final report & & & & & & & & & \\
\hline
\end{tabular}

\section{Participant's Handout \#7.2: Criteria for Scoring Potential Evaluators}

\begin{tabular}{|c|c|c|c|}
\hline Topic & $\begin{array}{l}\text { Maximum } \\
\text { points(e.g.) }\end{array}$ & $\begin{array}{l}\text { Initial } \\
\text { assessment }\end{array}$ & $\begin{array}{l}\text { Revised } \\
\text { assessment }\end{array}$ \\
\hline \multicolumn{4}{|l|}{ Organization and methodology } \\
\hline $\begin{array}{l}\text { Rationale (understanding of and reflection on the ToR, risks and } \\
\text { assumptions) }\end{array}$ & 20 & [score] & [score] \\
\hline Strategy (approach, activities, timetable, milestones, logical framework) & 40 & [score] & [score] \\
\hline \multicolumn{4}{|l|}{ Evaluation team } \\
\hline \multicolumn{4}{|l|}{$\begin{array}{l}\text { Experience (description of company/consortium, division of tasks). } \\
\text { For example: }\end{array}$} \\
\hline $\begin{array}{l}\text { (a) Experience in evaluations } \\
\text { (b) Experience with the program area } \\
\text { (c) Experience with SBCC program evaluation }\end{array}$ & 20 & [score] & [score] \\
\hline Experts (CVs, division of tasks) & 20 & [score] & [score] \\
\hline
\end{tabular}

1. Ask participants if they have any questions related to the ToR. 
Session 7.2: Preparing a Timeline for an Evaluation

Time: 60 minutes

\section{INSTRUCTIONS}

1. Make three groups of 6-7 people. Ask each group to discuss any SBCC health intervention program in their group and suggest a timetable for its evaluation indicating different line items for a ToR (total time 30 minutes).

2. Ask each group to present their timetable for a ToR by line items using flip chart. After presentation, suggest any adjustments to timetables and summarize (10 minutes for each group).

Session 7.3: Wrap-Up and Final Questions

Time: 60 minutes

\section{INSTRUCTIONS}

1. Restate major conclusions from each session and provide a general reminder of key points addressed (30 minutes).

2. Clarify final questions participants may have and administer the posttest (30 minutes). 


\section{ihbp \\ HEALTHY \\ PROGRAM}

The Family Health International (FHI 360)-managed Behavior Change Communication - Improving Healthy Behaviors Program (IHBP) in India project is a United States Agency for International Development (USAID)/India-funded program. IHBP aims to improve adoption of positive healthy behaviors through institutional and human resource capacity building of national and state institutions and through development of strong, evidence-based social and behavior change communication programs for government counterparts.

\section{IMPROVING HEALTHY BEHAVIORS PROGRAM (IHBP)}

$\mathrm{FHI} 360$

1825 Connecticut Avenue, NW

Washington, DC 20009

\section{- POPULATION COUNCIL \\ Ideas. Evidence. Impact.}

The Population Council confronts critical health and development issues-from stopping the spread of HIV to improving reproductive health and ensuring that young people lead full and productive lives. Through biomedical, social science, and public health research in 50 countries, we work with our partners to deliver solutions that lead to more effective policies, programs, and technologies that improve lives around the world. Established in 1952 and headquartered in New York, the Council is a nongovernmental, nonprofit organization governed by an international board of trustees.

\section{POPULATION COUNCIL}

Zone 5A, Ground Floor, India Habitat Center, Lodi Road, New Delhi 110003

Tel: 91-11-24642901/2, Fax: 91-11-24642903

Email: Info.india@popcouncil.org

www.popcouncil.org 
